\title{
Model senam lansia untuk kebugaran jasmani dan fungsi otak
}

\author{
Edo Fralian Putra *, S. Suharjana \\ Program Studi Ilmu Keolahragaan, Program Pascasarjana, Universitas Negeri Yogyakarta. \\ Jalan Colombo No. 1, Karangmalang, Yogyakarta 55281, Indonesia. \\ * Corresponding Author. Email: kotaksuratedo@gmail.com \\ Received: 30 July 2018; Revised: 26 September 2018; Accepted: 1 October 2018
}

\begin{abstract}
Abstrak
Penelitian ini bertujuan untuk menghasilkan sebuah senam lansia untuk kebugaran jasmani dan fungsi otak. Metode penelitian ini mengacu pada penelitian Borg \& Gall dengan tahapan: studi pendahuluan, analisis desain draf awal, validasi ahli, uji coba produk, evaluasi, dan revisi. Subjek uji coba skala kecil 15 orang, subjek uji coba penelitian skala besar 57 orang, dan subjek uji efektifitas produk 12 orang. Penilaian para ahli dan instruktur menggunakan kuisioner. Pengukuran kebugaran jasmani lansia menggunakan tes uji jalan 6 menit, sedangkan untuk mengukur fungsi kognitif lansia menggunakan tes The Montreal Cognitif Assesment Indonesia (MoCA-Ina). Hasil penelitian menunjukkan, model senam lansia valid, serta layak dan efektif untuk kebugaran jasmani dan fungsi otak. Hasil validasi ahli kesehatan lansia dan akademisi sekaligus praktisi kesehatan termasuk "sangat baik". Kualitas produk hasil uji coba skala kecil "sangat baik". Uji coba skala besar juga termasuk "sangat baik". Hasil uji efektifitas produk menunjukkan peningkatan kebugaran jasmani lansia 0,32 poin. Hasil uji efektifitas menunjukkan peningkatan fungsi kognitif lansia dengan 1,72 poin.
\end{abstract}

Kata Kunci: senam lansia, kebugaran jasmani, dan fungsi otak.

\section{Modelling the elder people gymnastics for physical fitness and cognitive function}

\begin{abstract}
The study aims at generating a gymnastic model the physical fitness and cognitive function of the elder people. In conducting the study, the method referred to the study by Borg \& Gall with the following sequence, preliminary study, initial draft design analysis, expert validation, product testing, evaluation, and revision. Then, the subjects that had been involved for the narrow-scale experiment were 15 people while the subjects that had been involved for the wide-scale experiment were 57 people and the subjects that had been involved for the product effectiveness test were 12 people. The assessment on the product by the experts and the instructors was gathered by means of questionnaire. In measuring the physical fitness of the elder people, the 6-minute walking test was administered. On the other hand, in measuring the cognitive function of the elder people the Montreal Cognitive Assessment Indonesia (MoCA-Ina) was administered. The results of the study show that the gymnastic model for the elder people is already valid and effective for maintaining the physical fitness and the cognitive function of the elder people. Furthermore, the results of the validation by the experts and the academicians on the health of the elder people as well as the health practitioners show that the gymnastic model belongs to the "Very Good" category. The results of the wide-scale experiment also show that the gymnastic model for the elder people belongs to the "Very Good" category. Last but not the least, the results of the product effectiveness test show improvement on both the physical fitness of the elder people and the cognitive function of the elder people.
\end{abstract}

Keywords: gymnastic elderly, physical fitness, and brain function.

How to Cite: Putra, E., \& Suharjana, S. (2018). Model senam lansia untuk kebugaran jasmani dan fungsi otak. Jurnal Keolahragaan, 6(2), 120-129. doi:https://doi.org/10.21831/jk.v0i0.20626

https://doi.org/10.21831/jk.v0i0.20626 


\section{Jurnal Keolahragaan 6 (2), 2018 - 121}

Edo Fralian Putra, S. Suharjana

\section{PENDAHULUAN}

Lanjut usia atau biasa disingkat dengan lansia merupakan salah satu fase atau siklus dalam kehidupan yang akan dialami oleh individu yang berumur panjang. Lansia adalah manusia yang mengalami pertambahan umur yang disertai dengan terjadinya berbagai penurunan kondisi fisik, penurunan fungsi dari organ-organ tubuh, serta penurunan fungsi dari otak.

Indonesia termasuk salah satu negara Asia yang pertumbuhan penduduk lansianya cepat. Data dari Badan Pusat Statistik menyebutkan, sejak tahun 2000, Indonesia sudah memiliki lansia sebesar 14,4 juta penduduk $(7,18 \%$ dari jumlah penduduk) dan pada tahun 2020 diperkirakan akan berjumlah 28,8 juta $(11,34 \%)$. Hasil pendataan yang dilakukan pada tahun 2007 ditemukan penduduk Lansia berjumlah 18,96 juta (8,42\% dari total penduduk) dengan komposisi perempuan $9,04 \%$ dan 7,80\% laki laki (Lanawati, 2015, p.1).

Peningkatan jumlah lansia seperti yang diperkirakan, tentunya dapat menimbulkan berbagai permasalahan, terutama di bidang kesehatan. Permasalahan di bidang kesehatan yang sering terjadi pada lansia antara lain penurunan kebugaran jasmani. Setelah umur 30 tahun terjadi penurunan kebugaran jantung paru $1 \%$ setiap umur bertambah satu tahun. Kebugaran jantung paru merupakan indikator pemakaian oksigen oleh jantung dan paru-paru, dimana pada usia 60 tahun kebugaran jantung paru akan berkurang 35\%. (Parwati, 2013, p.2). Sedangkan menurut menurut Rohana (2011. p. 17), penurunan kemampuan akan semakin terlihat setelah umur 40 tahun, sehingga saat lansia kemampuan akan turun antara 30-50\%.

Oleh sebab itu, sudah menjadi hukum alam ketika usia manusia bertambah, apabila tidak terlatih, maka tingkat kebugaran jasmaninya akan mengalami penurunan. Kebugaran jasmani adalah kualitas seseorang untuk melakukan aktivitas sesuai pekerjaannya secara optimal tanpa menimbulkan masalah kesehatan dan kelelahan berlebihan (Suharjana, 2008, p.264).

Pada lansia juga terjadi penurunan terhadap fungsi otak berupa demensia/kepikunan. Kartika (2013, p. 37) mengatakan fungsi otak terutama kemampuan untuk mengingat terus berkurang, ini karena hipotalamus, daerah pada otak yang bertanggung jawab terhadap ingatan terus kehilangan sel sarafnya sebanyak 5 persen setiap 10 tahun.
Fungsi otak yang menurun seiring dengan bertambahnya usia lainnya adalah penurunan pada aspek kognitif, yaitu penurunan fungsi pada memori/daya ingat, penurunan dalam kemampuan penamaan dan kecepatan mencari kembali informasi yang telah tersimpan dalam pusat memori. Seperti yang dijelaskan oleh Strub dan Black di antara fungsi otak yang menurun secara linier seiring dengan bertambahnya usia adalah fungsi memori (daya ingat) berupa kemunduran dalam kemampuan penamaan (naming) dan kecepatan mencari kembali informasi yang telah tersimpan dalam pusat memori (speed of information retrieval from memory) (Lanawati 2015, pp. 35-36).

Organisasi kesehatan dunia (WHO) seperti yang dikutip oleh Lanawati (2015, pp. 1-2) melaporkan bahwa, pada tahun 2012 penurunan fungsi kognitif pada lansia diperkirakan 121 juta manusia, dengan komposisi 5,8\% laki laki dan $9,5 \%$ perempuan. Gejala gangguan fungsi pada kognitif antara lain, gangguan pada memori/daya ingat, kehilangan keterampilan berbahasa dan berhitung, bahkan demensia/pikun.

Meningkatnya jumlah lansia di Indonesia, diperlukan perbaikan kualitas kesehatan para lansia. Lansia diharapkan dapat memiliki semangat untuk dapat hidup mandiri, memiliki rasa percaya diri, bugar dan energik, dan memiliki kualitas hidup yang baik. Seorang lansia dapat dikatakan berkualitas, apabila dapat melakukan aktivitas sehari-hari dengan mandiri, masih produktif dalam bekerja, memiliki daya ingat yang baik dan mempunyai kebugaran jasmani yang baik pula.

Pada lanjut usia penting untuk memiliki kemampuan fisik maupun kemampuan kognitif yang baik, sehingga bisa dikatakan sebagai lansia yang berkualitas. Salah satu upaya untuk mewujudkan lansia yang berkualitas adalah dengan melakukan olahraga. Olahraga sangat penting untuk menjaga kesehatan tubuh, terutama bagi lansia. Banyak hasil penelitian yang menyebutkan bahwa dengan berolahraga secara teratur bagi lansia dapat mengurangi risiko penyakit jantung, stroke, hipertensi, diabetes, dan osteoporosis, dan sebagainya. Selain itu, olahraga bagi lansia juga bermanfaat untuk membuat tidur nyenyak dan mengurangi depresi.

Bagi lansia dalam berolahraga perlu untuk berkonsultasi ke dokter terlebih dahulu dan memperhatikan prinsip-prinsip latihan seperti intensitas latihan, durasi latihan, dan frekuensi latihan. Seperti yang disampaikan oleh Pangastuti (2011, p. 34) yaitu, olahraga lansia sebaiknya terdiri atas 
latihan yang bersifat aerobik, latihan kekuatan, dan latihan keseimbangan serta kelenturan. Pemilihan olahraga untuk lansia juga harus memperhatikan kemampuan dari lansia tersebut.

Salah satu olahraga yang cenderung memberikan keuntungan yang besar bagi lansia adalah olahraga senam. Senam merupakan olahraga yang bersifat aerobik dan rekreasi. Senam juga memberikan manfaat, antara lain untuk mempertahankan bahkan meningkatkan taraf kebugaran jasmani serta membentuk kondisi fisik. Lebih dari pada itu, senam juga bermanfaat dalam membantu perkembangan otak karena senam merupakan kombinasi gerakan dan musik. Seperti yang disampaikan oleh Pradipta dan Sukoco (2013, p. 133) yaitu, perpaduan antara aktivitas jasmani/olahraga dengan mendengarkan musik dapat membantu perkembangan otak.

Senam merupakan olahraga yang bisa dikatakan sebagai olahraga yang aman untuk lansia, karena memiliki risiko cedera yang kecil buat lansia. Selain itu, senam juga merupakan olahraga rekreatif yaitu menyenangkan, dan mudah dilakukan, serta dosis latihan yang berjenjang naik secara perlahan dari latihan pemanasan, latihan inti, dan latihan pendinginan. Senam saat ini memang menjadi salah satu pilihan olahraga buat para lansia dalam menjaga kebugaran. Senam kebugaran untuk lansia juga telah banyak diciptakan.

Berdasarkan pengamatan penulis, senam lansia yang telah dibuat, banyak yang hanya berfokus pada satu aspek, misalnya kebugaran jasmani saja. Senam lansia juga belum mengklasifikasikan golongan lansia, baik pengklasifikasikan secara usia maupun tingkat kemampuan lansia, yaitu lansia terlatih atau lansia yang tidak terlatih.

Pengklasifikasian golongan lansia dalam membuat suatu model senam lansia sangat perlu dilakukan, karena tidak semua gerakan dan intensitas latihan yang diterapkan pada sebuah model senam cocok untuk semua golongan lansia. Selain itu, senam-senam yang telah dilakukan oleh para lansia di lapangan belum memperhatikan aspek kognitif. Sedangkan, penurunan terhadap fungsi kognitif, terutama gangguan pada memori/daya ingat, kehilangan keterampilan berbahasa dan berhitung, bahkan demensia/ pikun, juga terjadi pada lansia.

Berkaitan dengan permasalahan tersebut, peneliti berencana membuat sebuah model senam lansia untuk kebugaran jasmani dan fungsi otak lansia yang sesuai dengan prinsip-prinsip latihan (prinsip senam kebugaran jasmani dan senam otak) dan karakteristik lansia, sehingga lansia akan dapat hidup sehat dan mandiri.

\section{METODE}

Penelitian yang dilakukan ini menggunakan model penelitian pengembangan (research and development). Tujuannya untuk untuk mendapatkan sebuah model senam untuk mendukung kebugaran jasmani dan fungsi otak lansia.

Waktu yang dilakukan dalam penelitian model senam lansia ini, yaitu bulan Maret 2016 sampai dengan bulan Oktober 2017. Sedangkan tempat penelitian yaitu, kelompok lansia mawar, kelompok senam lansia joglo, dan kelompok senam lansia Banjarejo.

Subjek penelitian yang diambil dalam penelitian ini adalah seorang pakar kesehatan lansia dan seorang praktisi senam lansia dalam uji pakar atau expert judgement. Pada uji coba skala kecil terdapat 15 orang lansia dari kelompok lansia mawar dan 2 orang instruktur senam lansia sebagai praktisi.

Dalam uji coba skala besar terdapat 57 orang lansia dari kelompok lansia joglo dan 2 orang instruktur senam lansia sebagai praktisi. Sedangkan untuk uji efektifitas terdapat 12 orang lansia dari kelompok senam lansia Banjarejo.

Prosedur penelitian dan pengembangan yang dilakukan dalam penelitian ini menggunakan modifikasi dari metode Gall, Gall, dan Borg (1996) yang antara lain sebagai berikut: (1) pengumpulan informasi di lapangan, (2) melakukan analisis terhadap informasi yang telah dikumpulkan, (3) pengembangan produk awal (draft model), (4) validasi ahli dan revisi, (5) uji coba skala kecil dan revisi, uji coba skala besar dan revisi, (7) pembuatan produk final.

Uji coba produk dalam penelitian ini dilakukan dalam dua tahap yaitu: (a) uji coba skala kecil, dan (b) uji coba skala besar. Setelah itu dilakukan uji efektifitas produk menggunakan metode eksperimen one group pretest postest.

Jenis data awal yang diperoleh pada penelitian ini adalah data kualitatif dan data kuantitatif. Pengumpulan data kualitatif didapatkan dari hasil wawancara para lansia dan instruktur senam lansia. Data kuantitatif diperoleh dari ahli materi terhadap draft produk, serta dari instuktur senam lansia pada uji coba lapangan.

Instrumen dalam penelitian ini yaitu menggunakan uji validitas dari pakar dengan lembar validasi. Uji coba skala kecil dan uji coba skala besar menggunakan lembar angket. Untuk mengukur kebugaran jasmani lansia digunakan tes uji jalan 6 menit. Sedangkan, untuk mengukur fungsi 
otak (kognitif) lansia menggunakan tes The Montreal Cognitif Assesment Indonesia (MoCAIna).

Setelah draf produk dibuat maka hal selanjutnya adalah menganalis draf produk senam lansia untuk kebugaran jasmani dan fungsi otak lansia dengan mengacu pada data yang berupa total skor yang diperoleh dari hasil penjumlahan skor item yang diberikan oleh ahli. Produk dianggap layak untuk diujicobakan dengan skala kecil maupun skala besar secara kuantitatif, apabila skor mencapai standar minimal kelayakan. Skor yang diperoleh terlebih dahulu diubah menjadi nilai persentase dengan menggunakan rumus sebagai berikut.

$$
\text { Penilaian }=\frac{\text { Skor yang diperoleh }}{\text { Skor Maksimal }} \times 100
$$

Setelah skor mentah diubah menjadi nilai persentase, kemudian dikonversikan dengan menggunakan norma penilaian yang mengacu pada penilaian acuan patokan (PAP) dengan bentuk rentang skor seperti pada Tabel 1.

Tabel 1. Rentang Skor Nilai PAP

\begin{tabular}{ccl}
\hline No. & Rentang Skor Nilai & \multicolumn{1}{c}{ Keterangan } \\
\hline 1. & $80 \%-100 \%$ & Sangat Baik \\
2. & $70 \%-79 \%$ & Baik \\
3. & $60 \%-69 \%$ & Cukup Baik \\
4. & $45 \%-59 \%$ & Kurang Baik \\
5. & $>44 \%$ & Sangat Kurang Baik \\
\hline & & (Sudijono, 2012, p. 319)
\end{tabular}

Sedangkan untuk menganalisis data hasil uji keefektifan yaitu dengan menggunakan uji $\mathrm{t}$ (dependent sample t-test) paired sample t-test menggunakan program SPSS 21 for windows. Data hasil aplikasi SPSS 21 ini dijabarkan dalam bentuk data kualitatif yang menunjukkan kelayakan produk. Adapun prasyarat yang harus dipenuhi sebelum melakukan uji $\mathrm{t}$ antara lain adalah uji normalitas (Kolmogrov-Sminof) dan uji homogenitas. Data yang diperoleh dapat dikatakan terdistribusi normal apabila memiliki nilai probabilitas lebih besar dari 0.05 ( $p>0.05)$.

\section{HASIL DAN PEMBAHASAN}

Analisis kebutuhan merupakan cara yang dilakukan untuk mengurai inti permasalahan melalui tinjauan langsung di lapangan baik dengan para pelaku utama sebagai pemberi atau penerima. Pada penelitian ini, model senam lansia untuk kebugaran jasmani dan fungsi otak juga dikembangkan berdasarkan analisis kebutuhan yang dilakukan dengan cara wawancara dengan instruktur senam dan beberapa lansia yang merupakan peserta senam lansia.

Hasil wawancara yang telah dilakukan, ditemukan beberapa permasalahan diantaranya adalah, senam lansia yang telah banyak dibuat belum mengklasifikasikan golongan lansia, baik pengklasifikasikan secara usia maupun tingkat kemampuan lansia, yaitu lansia terlatih atau lansia yang tidak terlatih. Pengklasifikasian golongan lansia dalam membuat suatu model senam lansia sangat perlu dilakukan, karena tidak semua gerakan dan intensitas latihannya yang diterapkan pada sebuah model senam cocok untuk semua golongan lansia. Selain itu, senam-senam yang telah dibuat untuk lansia lebih banyak terfokus pada satu aspek, misalnya kebugaran jasmani.

Permasalahan lansia tidak hanya tentang aspek kebugaran jasmaninya saja, tetapi pada lansia juga terjadi penurunan terhadap fungsi otak. Fungsi otak yang menurun seiring dengan bertambahnya usia adalah penurunan pada aspek kognitif, yaitu penurunan fungsi pada memori/ daya ingat, penurunan dalam kemampuan penamaan dan kecepatan mencari kembali informasi yang telah tersimpan dalam pusat memori.

Berdasarkan analisis kebutuhan tersebut, dapat disimpulkan bahwa pengembangan sebuah model senam lansia untuk kebugaran jasmani dan fungsi otak tepat untuk dilakukan dan sesuai dengan kebutuhan di lapangan.

Produk yang dihasilkan dalam penelitian dan pengembangan ini berupa senam untuk mendukung kebugaran jasmani dan fungsi otak lansia yang berbentuk $\mathrm{CD} /$ compact disc. Pengembangan produk senam lansia ini untuk membantu para lansia dalam menjaga, dan melatih kebugaran jasmani, serta fungsi otaknya yaitu fungsi kognitifnya.

Perencanaan desain model senam lansia untuk kebugaran jasmani dan fungsi otak meliputi, analisis rangkaian gerakan senam, mulai dari penyusunan sistematika gerakan sampai dengan gerakan senam yang sesuai untuk lansia dan dirancang sesuai dengan prinsip-prinsip latihan. Selanjutnya, melakukan analisis terhadap karakteristik usia lansia, yaitu menganalisa gerakan senam sehingga mudah, dan aman, untuk dilakukan oleh lansia serta sesuai dengan keadaan lansia dan tingkat keterlatihan dari lansia. Kemudian melakukan analisis tujuan pengembangan model senam ini dibuat. Senam ini dibuat dengan tujuan untuk menjaga, melatih, serta memelihara kebugaran jasmani dalam hal ini kebugaran kardiovaskulernya para lansia, dan 


\section{Jurnal Keolahragaan 6 (2), 2018 - 124}

Edo Fralian Putra, S. Suharjana

untuk menjaga kemampuan fungsi otak lansia, yaitu fungsi kognitifnya.

Validasi ahli dilakukan dengan cara menyampaikan desain draft produk awal secara tertulis disertakan dengan video draft senam lansia dan lembar evaluasi. Lembar evaluasi yang disampaikan berisi saran dan komentar tentang model senam lansia untuk kebugaran jasmani dan fungsi otak.

Rangkuman data hasil validasi ahli dalam tahap draf model senam lansia untuk mendukung kebugaran jasmani dan fungsi otak, dapat dilihat pada Tabel 2. Pada Tabel 2, menunjukkan bahwa ran-cangan produk model senam lansia untuk kebu-garan jasmani dan fungsi otak termasuk dalam kategori sangat baik (80\%-100\%) dengan persen-tase sebesar $81,87 \%$ dan dapat diujicobakan pada tahap selanjutnya yaitu uji coba produk.

Saran dari ahli juga didapatkan pada tahap validasi ahli ini. Praktisi kesehatan lansia menyarankan yaitu keseimbangan dalam gerak pada gerakan senam diperlukan, dan sistematika penyusunan gerakan senam perlu diperhatikan. Sedangkan dari Akademisi sekaligus Praktisi senam lansia menyarankan untuk, memperperhatikan lansia yang memiliki masalah seperti obesitas, tekanan darah tinggi, dan lain-lain.

Hasil evaluasi ahli secara keseluruhan menunjukkan bahwa produk penelitian ini layak untuk diuji cobakan pada tahap berikutnya dengan merevisi draft sesuai dengan saran dan masukan yang sudah diberikan. Selanjutnya dapat diuji cobakan pada tahap berikutnya yaitu uji coba kelompok kecil.

Uji coba produk adalah tahapan yang harus dilalui untuk mendapatkan data penilaian terhadap media yang dikembangkan dengan menggunakan instrumen angket, sedangkan untuk efektifitas media yang dikembangkan, pengukuran dilakukan melalui penelitian eksperimen dengan tes dan pengukuran.

Tahap uji coba terbagi menjadi 3 tahapan yakni uji coba skala kecil, uji coba skala besar, dan uji efektifitas. Instrumen angket digunakan saat uji coba skala kecil, skala besar. Sedangkan, uji efektifitas menggunakan tes dan pengukuran. Untuk mengukur kebugaran kardiovaskuler lansia menggunakan uji jalan 6 menit, dan untuk mengukur fungsi kognitif menggunakan The Montreal Cognitif Assesment Indonesia (MoCAIna).

Tahap uji coba ini dilakukan sebagai upaya untuk mengetahui tanggapan awal dan keberterimaan dari produk yang dikembangkan. Keberterimaan terhadap produk latihan diketahui berdasarkan pengisian kuesioner yang telah disediakan.

Tabel 2. Rangkuman Data Hasil Validasi Ahli

\begin{tabular}{cccccc}
\hline No. & Ahli & Skor Hasil & Skor Maksimal & $\%$ & Keterangan \\
\hline 1. & Praktisi Kesehatan Lansia & 66 & 80 & $82,50 \%$ & Sangat Baik \\
2. & Akademisi dan Praktisi Senam Lansia & 65 & 80 & $81,25 \%$ & Sangat Baik \\
& Jumlah & 131 & 160 & $81,87 \%$ & Sangat Baik \\
\hline
\end{tabular}

Tabel 3. Hasil Penilaian Praktisi Uji coba Skala Kecil

\begin{tabular}{cccccc}
\hline No. & Praktisi & Skor Hasil & Skor Maksimal & $\%$ & Keterangan \\
\hline 1. & Instruktur Senam dan Akademisi & 68 & 80 & $85,00 \%$ & Sangat Baik \\
2. & Instruktur Senam Lansia & 70 & 80 & $87,50 \%$ & Sangat Baik \\
& Jumlah & 138 & 160 & $86,25 \%$ & Sangat Baik \\
\hline
\end{tabular}

Tabel 4. Revisi terhadap Produk

\begin{tabular}{cll}
\hline No. & \multicolumn{1}{c}{ Sebelum Revisi } & \multicolumn{1}{c}{ Sesudah Revisi } \\
\hline 1. & Tambahkan Gerakan menyilang tubuh & Gerakan menyilang tubuh telah ditambahkan \\
2. & Gerakan inti kurang bervariasi & Gerakan inti sudah bervariasi \\
3. & Perbanyak pengulangan di beberapa bagian, terutama & $\begin{array}{l}\text { Pengulangan di beberapa bagian inti sudah } \\
\text { ditambah }\end{array}$ \\
\hline
\end{tabular}

Tabel 5. Hasil Penilaian Praktisi Uji Coba Skala Besar

\begin{tabular}{cccccc}
\hline No. & Praktisi & Skor Hasil & Skor Maksimal & $\%$ & Keterangan \\
\hline 1. & Praktisi Senam dan Akademisi & 78 & 80 & $97,50 \%$ & SangatBaik \\
2. & Instruktur Senam Lansia & 79 & 80 & $98,75 \%$ & Sangat Baik \\
& Jumlah & 157 & 160 & $98,12 \%$ & Sangat Baik \\
\hline
\end{tabular}




\section{Jurnal Keolahragaan 6 (2), 2018 - 125}

Edo Fralian Putra, S. Suharjana

Kuesioner berisi pertanyaan terkait dengan aspek-aspek produk yang dikembangkan. Respon subyek penelitian terhadap produk yang dikembangkan menjadi bahan evaluasi bagi peneliti dalam memperbaiki produk

Uji coba skala kecil dilakukan terhadap Kelompok Senam Lansia Mawar pada tanggal 31 Juli 2017, yang bertempat di Kepuh, Gondokusuman, Yogyakarta. Jumlah subjek pada uji coba skala kecil ini sebanyak 15 orang lansia yang terdiri dari 11 orang lansia perempuan dan 4 orang lansia laki-laki.

Dari uji coba skala kecil didapatkan data hasil berupa evaluasi dengan menggunakan angket untuk praktisi yaitu instruktur senam sekaligus akademisi dan instruktur senam lansia.

Data hasil penilaian para praktisi terhadap produk pada uji coba skala kecil dapat dilihat pada Tabel 3. Tabel 3 menunjukkan bahwa produk model senam lansia untuk kebugaran jasmani dan fungsi otak termasuk dalam kategori sangat baik (80\%-100\%) dengan persentase sebesar $86,25 \%$.

Dengan hasil yang demikian, maka pengembangan ini sangat layak untuk diteruskan ke uji coba skala besar, untuk melihat seberapa layakkah hasil yang didapat dengan jumlah orang coba lebih banyak dan dari tempat yang berbeda.

Saran dari ahli juga didapatkan pada tahap penilaian uji coba skala kecil ini. Berdasarkan saran para ahli terhadap senam lansia untuk kebugaran jasmani dan fungsi otak ini, maka akan dilakukan revisi terhadap produk sebelum uji coba skala besar dilaksanakan. Revisi terhadap produk dijelaskan pada Tabel 4.

Setelah uji coba kelompok kecil selesai dilaksanakan, maka dilanjutkan tahap berikutnya yaitu uji coba kelompok besar. Uji coba skala besar dilakukan sebagai upaya untuk mengetahui keberterimaan produk dalam lingkup yang lebih luas.

Uji coba skala besar dilakukan terhadap Kelompok Senam Lansia Joglo pada tanggal 15 Agustus 2017, yang bertempat di Peleman, Kota Gede, Yogyakarta. Jumlah subjek pada uji coba skala besar ini sebanyak 57 orang lansia yang terdiri dari 49 orang lansia perempuan dan 11 orang lansia laki-laki.

Data hasil penilaian para praktisi terhadap produk pada uji coba skala besar dapat dilihat pada Tabel 5. Tabel 5 menunjukkan bahwa produk model senam lansia untuk kebugaran jasmani dan fungsi otak termasuk dalam kategori sangat baik (80\%-100\%) dengan persentase sebesar $98,12 \%$. Dengan hasil yang demikian, maka pengembangan ini sangat layak untuk diteruskan ketahapan selanjutnya yaitu uji efektifitas.

Tujuan dari pelaksanaan uji efektifitas adalah untuk mengetahui kelayakan model senam lansia untuk kebugaran jasmani dan fungsi otak. Data uji efektifitas produk didapatkan dari hasil pengukuran kebugaran jasmani dan pengukuran fungsi otak (kognitif) lansia, sebelum dan sesudah mendapatkan treatment senam lansia.

Uji efektifitas dilakukan di kelompok senam lansia Banjarejo Kabupaten Purworejo selama 5 Minggu yaitu tanggal 28 Agustus 20171 Oktober 2017 dengan jumlah 12 orang. Uji efektifitas merupakan pengujian produk final yang sudah terbentuk untuk mengetahui kelayakan dan keberhasilan penelitian model senam lansia untuk kebugaran jasmani dan fungsi otak.

Uji efektifitas produk menggunakan metode eksperimen one group pretest postest selama selama 5 minggu dengan 15 kali pertemuan. Pemilihan waktu 5 minggu mengacu pada penelitian yang dilakukan oleh Lengkong, Marunduh, \& Wungow (2016) yaitu, lansia yang melakukan senam bugar lansia yang diterapkan selama 5 minggu terdapat peningkatan yang signifikan pada kebugaran jasmani lansia. Selain itu, penelitian yang dilakukan oleh Pusat Penelitian kesehatan UNIKA Atma Jaya, lansia yang melakukan senam vitalitas otak sebanyak $2 \mathrm{kali} / \mathrm{seminggu}$ selama setahun menunjukkan fungsi kognitif dan keseimbangan yang lebih baik dibandingkan dengan kelompok lansia yang tidak melakukan senam (Turana, 2013, p.19).

Gambar 1 merupakan desain penelitian untuk uji efektifitas. Uji efektifitas produk menggunakan metode eksperimen one group pretest postest.

D, $\times \mathrm{D}_{\mathbf{2}}$

Gambar 1. Desain Penelitian Eksperimen One Group Pretest Posttest

Keterangan Gambar:

$\mathrm{O}_{1}=$ Pretest (sebelum diberikan perlakuan senam lansia istimewa)

$\mathrm{O}_{2}=$ Posttest (sesudah diberikan perlakuan senam lansia istimewa).

Berdasarkan Tabel 6 yang ditampilkan diatas, maka secara keseluruhan dapat simpulkan bahwa setelah melakukan model senam lansia, kebugaran jasmani para lansia mengalami peningkatan. Hal ini dapat terlihat berdasarkan pada jarak tempuh lansia pada saat pelaksanaan pretest dan posttest. 
Tabel 6. Data Pretest dan Posttest Hasil Jarak Tempuh Uji Jalan 6 menit Lansia

\begin{tabular}{ccccc}
\hline \multicolumn{3}{c}{ Jarak yang Ditempuh $(\mathrm{m})$} \\
\hline \multicolumn{3}{c}{ Laki-laki } & \multicolumn{2}{c}{ Perempuan } \\
\hline Pretest & Posttest & Pretest & Posttest \\
\hline Rata-rata & 520 & 548 & 425 & 458 \\
\hline
\end{tabular}

Tabel 7. Data Pretest dan Postest Hasil Fungsi Kognitif Lansia

\begin{tabular}{ccccc}
\hline & \multicolumn{3}{c}{ Kognitif Lansia } \\
\hline & Pretest & \multicolumn{2}{c}{ Postest } \\
\hline Normal & $\begin{array}{c}\text { Tidak } \\
\text { Normal }\end{array}$ & Normal & $\begin{array}{c}\text { Tidak } \\
\text { Normal }\end{array}$ \\
\hline Rata-rata & 7 & 5 & 12 & 0 \\
\hline
\end{tabular}

Berdasarkan Tabel 7, terjadi peningkatan fungsi otak (kognitif) pada lansia. Pada saat pretest 7 orang lansia berada pada kategori kognitif normal, dan 5 orang berada pada kategori kognitif tidak normal. Sedangkan pada posttest semua lansia berada pada kategori kognitif normal, yaitu 12 orang.

Pengujian normalitas data pada penelitian ini menggunakan metode Kolmogorov-Smirnov. Uji normalitas data bertujuan untuk mengetahui normalitas sebaran data penelitian. Hasil uji normalitas data dapat dilihat pada Tabel 8 .

Tabel 8. Hasil Uji Normalitas Data Kebugaran Jasmani (Kardiovaskuler) Lansia.

\begin{tabular}{ccc}
\hline Data & Sig & Kesimpulan \\
\hline Pretest & 0,121 & Normal \\
Posttest & 0,200 & Normal \\
\hline
\end{tabular}

Berdasarkan Tabel 8, hasil uji normalitas data, diketahui bahwa keseluruhan $\mathrm{p}$ value pada variabel kebugaran jasmani (kardiovaskuler) lansia pada saat pretest maupun posttest menunjukkan $>0,05$.

Tabel 9. Hasil Uji Normalitas Data Fungsi Otak (kognitif) Lansia.

\begin{tabular}{ccc}
\hline Data & Sig & Kesimpulan \\
\hline Pretest & 0,200 & Normal \\
Posttest & 0,200 & Normal \\
\hline
\end{tabular}

Berdasarkan Tabel 9 hasil uji normalitas data, diketahui bahwa keseluruhan $\mathrm{p}$ value pada variabel fungsi otak (kognitif) lansia pada saat pretest maupun posttest menunjukkan $>0,05$.
Dengan demikian, dapat disimpulkan bahwa tidak ada perbedaan frekuensi observasi (hasil) dengan frekuensi harapan normal, berarti semua data pada penelitian ini berdistribusi normal. Sehingga, semua data pada penelitian ini memenuhi asumsi normalitas sebaran.

Setelah mengetahui uji normalitas data maka dilakukan pengujian homogenitas. Pengujian homogenitas dilakukan dengan tujuan untuk menguji kesamaan varians pada populasi. Uji homogenitas variansi populasi pada penelitian ini dilakukan dengan uji F. Hasil uji homogenitas secara ringkas dapat dilihat pada Tabel 10.

Tabel 10. Hasil Uji Homogenitas Data.

\begin{tabular}{ccc}
\hline Variabel & Sig & Kesimpulan \\
\hline Kebugaran Jasmani & 0,895 & Homogen \\
Fungsi Kognitif & 0,146 & Homogen \\
\hline
\end{tabular}

Berdasarkan data pada tabel 10, hasil uji homogenitas untuk variabel kebugaran jasmani (kardiovaskuler) lansia menunjukkan $p$ value $(0,895)>0,05$. Sedangkan untuk variabel fungsi otak (kognitif) lansia menunjukkan $p$ value $(0$, 146) $>0,05$.

Dengan demikian, keseluruhan data kebugaran jasmani lansia bersifat homogen. Hasil analisis data menunjukkan bahwa data penelitian normal dan homogen sehingga memenuhi syarat untuk dilakukan uji Signifikansi (efektifitas)

Uji Signifikansi (efektifitas) menggunakan paired $t$-test untuk mengetahui pengaruh model senam lansia untuk kebugaran jasmani dan fungsi otak (treatment) yang diberikan terhadap status kebugaran jasmani (kardiovaskuler) dan fungsi otak (kognitif) lansia subjek penelitian.

Berdasarkan data pada Tabel 11, dapat dilihat bahwa pada variabel kebugaran jasmani terdapat perubahan berupa peningkatan rata-rata sebesar 0,32 poin dari hasil pretest sebesar 4,409 poin dan hasil posttest sebesar 4,729 poin yang bermakna terjadi peningkatan rata-rata variabel kebugaran jasmani pada subjek penelitian. Hasil perhitungan paired t-test diketahui bahwa nilai sig. ( 2 tailed) sebesar 0,000 . Karena nilai sig. (2 tailed) sebesar $0,000<0,05$ maka terdapat perbedaan dan pengaruh yang signifikan antara hasil pretest dengan posttest.

Tabel 11. Hasil Uji Signifikansi (Efektifitas).

\begin{tabular}{|c|c|c|c|c|}
\hline \multirow{2}{*}{ Variabel } & \multicolumn{2}{|c|}{ Mean } & \multirow{2}{*}{ Sig. } & \multirow{2}{*}{ Ket. } \\
\hline & Pre & Post & & \\
\hline Kebugaran Jasmani (kardiovaskuler) & 4,409 & 4,729 & 0,000 & signifikan \\
\hline Fungsi Otak (kognitif) & 25,583 & 27,333 & 0,005 & signifikan \\
\hline
\end{tabular}




\section{Jurnal Keolahragaan 6 (2), 2018 - 127}

Edo Fralian Putra, S. Suharjana

Sedangkan, pada variabel fungsi otak (kognitif) lansia terdapat perubahan berupa peningkatan rata-rata sebesar 1,75 poin dari hasil pretest sebesar 25,583 poin dan hasil posttest sebesar 27,333 poin yang bermakna terjadi peningkatan rata-rata variabel fungsi kognitf pada subjek penelitian. Hasil perhitungan uji paired t-test diketahui bahwa nilai sig. (2 tailed) sebesar 0,005 . Karena nilai sig. (2 tailed) sebesar $0,005<0,05$ maka terdapat perbedaan dan pengaruh yang signifikan antara hasil pretest dengan posttest.

Dengan demikian, dapat disimpulkan bahwa model senam lansia untuk kebugaran jasmani dan fungsi otak efektif dalam meningkatkan kebugaran jasmani dan fungsi otak (kognitif) lansia. Model latihan yang dikembangkan terbukti berpengaruh terhadap perbaikan kebugaran jasmani dan fungsi otak para lansia. Model senam yang dikembangkan mampu memperbaiki kebugaran jasmani para lansia sebesar 0,32 poin serta memperbaiki fungsi otak (kognitif) para lansia sebesar 1,75 poin.

Hasil penelitian yang telah diperoleh menunjukkan jawaban atas hipotesis yang dipaparkan sebelumnya. Dari hasil yang telah didapat maka diperoleh pembahasan sebagai berikut.

Hipotesis Pertama terbukti bahwa model senam lansia layak untuk para lansia, terutama bagi mereka yang berusia 55-65 tahun. Uji coba dilakukan dengan membagikan kuesioner kepada observator, yaitu seorang praktisi senam sekaligus akademisi, dan juga seorang instruktur senam lansia. Hasil uji coba skala kecil menunjukkan bahwa rancangan produk model senam lansia ini termasuk dalam kategori sangat baik dengan persentase perolehan total rata-rata skor sebesar $86,25 \%$. Hasil uji coba skala besar, juga termasuk dalam kategori sangat baik dengan persentase perolehan total rata-rata skor sebesar $98,12 \%$. Penilaian uji coba skala kecil dilakukan untuk mengetahui model senam lansia yang dikembangkan memberikan manfaat dan sesuai untuk para lansia usia pada skala kecil. Sedangkan penilaian uji coba skala besar untuk mengetahui kesesuaian/kecocokan pada skala yang lebih besar. Permasalahan yang dialami lansia antara lain perubahan secara fisik dan perubahan secara sosial. Pangastuti (2011, p.33) mengatakan lansia memiliki berbagai masalah kesehatan yang berasal dari empat aspek yaitu, fisik, psikologi, sosial, dan ekonomi. Beberapa masalah perubahan fisik yang sering terjadi pada lansia antara lain penurunan tingkat kebugaran jasmani. Menurut Rohana (2011, p. 17), penurunan ke- mampuan akan semakin terlihat setelah umur 40 tahun, sehingga saat lansia kemampuan akan turun antara 30-50\%. Oleh sebab itu, sudah menjadi hukum alam ketika usia manusia bertambah, apabila tidak terlatih, maka tingkat kebugaran jasmaninya akan mengalami penurunan. Kemunduran lain yang sering terjadi pada lansia adalah penurunan pada fungsi otak yaitu gangguan pada fungsi kognitif. Organisasi kesehatan dunia (WHO) seperti yang dikutip oleh Lanawati (2015, pp. 1-2) melaporkan bahwa, pada tahun 2012 penurunan fungsi kognitif pada lansia diperkirakan 121 juta manusia, dengan komposisi 5,8\% laki laki dan 9,5\% perempuan. Gejala gangguan fungsi pada kognitif antara lain, gangguan pada memori/daya ingat, kehilangan keterampilan berbahasa dan berhitung, bahkan demensia/ pikun. Hasil dari uji coba skala kecil dan uji coba skala besar apabila dibandingkan terdapat peningkatan persentase skor dari $86,25 \%$ menjadi $98,12 \%$. Peningkatan persente skor sebesar $11,87 \%$ menunjukkan bahwa ada peningkatan perbaikan model senam lansia yang telah dikembangkan. Model senam lansia yang dikembangkan menjadi lebih layak digunakan bagi para lansia.

Hipotesis kedua terbukti bahwa model senam ini sesuai untuk mendukung kebugaran jasmani dan fungsi otak lansia. Hasil yang menyatakan bahwa model senam lansia sesuai, serta aman dilakukan oleh para lansia adalah validator. Pada saat penyelesaian tahap pengembangan model senam lansia dilakukan tahap validasi oleh para ahli. Ahli materi yang ditunjuk adalah seorang praktisi kesehatan lansia dan seorang akademisi sekaligus praktisi senam lansia. Ahli materi (Praktisi Kesehatan Lansia) menilai tentang aktivitas senam harus sesuai dengan prinsipprinsip senam dan latihan. Ahli materi (Akademisi dan Praktisi senam lansia) menilai tentang gerakan-gerakan yang sesuai bagi lansia dan sistematika penyusunan sebuah senam. Model senam lansia yang dikembangkan sudah sesuai dengan prinsip-prinsip senam dan latihan. Pada senam ini terdapat 25 gerakan yang bervariasi dan berkategorikan "low impact" yang terdiri atas, gerakan sikap sempurna sebagai awalan, gerakan pemanasan, gerakan peralihan sebanyak 9 gerakan, gerakan inti kebugaran jasmani sebanyak 8 gerakan, gerakan inti untuk fungsi otak, gerakan pendinginan, dan ditutup oleh gerakan sikap sempurna di akhir. Senam lansia ini berdurasi 30 menit dengan intensitas latihan $70 \%$ - $80 \%$ denyut nadi maksimum, sehingga dapat dilakukan 3 kali dalam seminggu bagi lansia yang 
belum terlatih. Bagi para lansia yang sudah terlatih, bisa melakukan senam ini dengan frekuensi latihan 3-5 kali per minggu dengan penambahan power di setiap gerakan. Hal ini sesuai dengan apa yang disampaikan oleh Pangastuti (2011, p.34) yaitu, olahraga pada lansia sebaiknya terdiri dari latihan aerobik untuk kesehatan jantung dan paru, latihan kekuatan, dan latihan keseimbangan dan kelenturan dengan memperhatikan durasi latihan, intensitas latihan dan frekuensi latihan. Durasi latihan bagi lanjut usia untuk latihan daya tahan adalah 20-30 menit/ hari merata bertahap dalam 1 minggu. Frekuensi latihan 4 kali dalam seminggu dengan intesitas latihan $50-75 \%$ dari denyut nadi maksimum Martono dan Darmojo, 2011, p.106). Hasil validasi yang telah dilakukan dalam penelitian ini menunjukkan bahwa rancangan produk model senam lansia untuk kebugaran jasmani dan fungsi otak termasuk dalam kategori valid. Data yang diperoleh dari para ahli menunjukkan sebesar $81,87 \%$ yang berarti pada rentan $80 \%-100 \%$ aman untuk diujicobakan.

Hipotesis ketiga terbukti bahwa model senam lansia efektif bagi para lansia. Hal ini dapat dibuktikan dari hasil uji efektifitas pengembangan produk yang telah dilakukan selama 5 Minggu dengan 15 kali pertemuan. Hasil penelitian menunjukkan terdapat perubahan berupa perbaikan rata-rata kebugaran jasmani lansia para lansia sebesar 0,32 poin serta peningkatan fungsi otak (kognitif) para lansia sebesar 1,75 poin. Hal ini bermakna terjadi perubahan dan peningkatan pada subjek penelitian. Penelitian yang dilakukan oleh Lengkong, Marunduh, \& Wungow (2016) tentang efek senam kebugaran lansia terhadap kebugaran jantung paru lansia, dijelaskan bahwa jarak tempuh lansia sebelum diberikan program senam (pretest) memiliki rata-rata jarak tempuh 91,93 meter, sedangkan setelah dilakukan program senam (posttest) sampel memiliki rata-rata jarak tempuh sejauh 93,33 meter. Hasil dari penelitian Lengkong, Marunduh, \& Wungow (2016) adalah dengan senam bugar lansia yang diterapkan selama 5 minggu pada lansia terdapat peningkatan yang signifikan pada kebugaran jasmani lansia. Sedangkan pada penelitian lainnya, Martini (2016) menyatakan senam otak dapat meningkatkan daya ingat (fungsi kognitif) pada lansia. Hal ini terlihat dari perubahan rata-rata skor fungsi kognitif sebelum dilakukan senam otak adalah 15,03 (pretest), sedangkan sesudah dilakukan senam otak adalah 19,92 (posttest). Penelitian ini juga diperkuat dengan hasil penelitian yang dilakukan oleh Satoh, et al. (2014) yaitu latihan yang dikombinasikan dengan musik menghasilkan efek positif lebih terhadap fungsi kognitif lansia dan kondisi fisik lansia pada umumnya. Pendapat yang sama juga dikemukakan oleh Han, et al (2016) bahwa, aktivitas fisik, terapi tarian, dan senam membantu mengurangi depresi dan meningkatkan fungsi kognitif pada lansia. Berdasarkan penjelasan tersebut maka model senam bugar lansia dan senam vitalisasi otak yang dikembangkan sesuai bagi lansia. Hal ini menunjukkan bahwa model senam lansia untuk kebugaran jasmani dan fungsi otak yang dikembangkan oleh peneliti dapat diterima bagi lansia dan sesuai dengan hasil penelitian yang telah dilakukan sebelumnya.

\section{SIMPULAN}

Telah dikembangkan suatu model senam lansia yang mendukung kebugaran jasmani dan fungsi otaknya, dengan durasi 29 menit 36 detik (30 menit), dan terdiri dari 25 gerakan termasuk pemanasan, gerakan inti kebugaran jasmani, gerakan inti otak, dan pendinginan, dengan intensitas latihan berkisar antara 70-80\% denyut nadi maksimal. Model telah teruji kelayakannya, baik secara teoritis maupun empirik, dan teruji juga keefektifitasnya untuk meningkatkan kebugaran jasmani/kardiovaskuler lansia (uji jalan 6 menit/ six minutes walk test) dan fungsi otak/ kognitif lansia (The Montreal Cognitif Assesment Indo-nesia/Tes MoCA-Ina) dengan frekuensi latihan 3 kali dalam seminggu selama 5 minggu.

\section{DAFTAR PUSTAKA}

Gall, M. D., Borg, W. R., \& Gall, J. P. (1996). Educational research: An introduction. Longman Publishing.

Han, Y. S., Araki, T., Lee, P. Y., Choi J. H., Kwon, I. S., Kwon, K. N., \& Kim J. Y. (2016). Development and effect a cognitive enhancement gymnastics program for elderly people with dementia. Journal of Exercise Rehabilitation. 12(4), doi: 10.12965/jer.1632624.312.

Kartika, U. (2013). 7 cara tingkatkan kemampuan otak. Kompas. Retrived from https://lifestyle.kompas.com/read/2013/09 /15/0942405/7.Cara.Tingkatkan.Kemamp uan.Otak.

Lanawati. (2015). Hubungan antara senam kebugaran jasmani lansia dengan fungsi kognitif dan keseimbangan tubuh di posyandu lansia Desa Dauh Puri Kauh 


\section{Jurnal Keolahragaan 6 (2), 2018 - 129}

Edo Fralian Putra, S. Suharjana

Denpasar. Tesis Magister, tidak dipublikasikan. Universitas Udayana.

Lengkong, G., Marunduh, S. R., \& Wungow, H. I. (2016). Pengaruh senam bugar lansia terhadap kebugaran jantung paru di Panti Werdha Bethania Lembean. Jurnal $e$ Biomedik, 4(2), pp. 1-5

Martini, A. (2016). Pengaruh senam otak terhadap perubahan daya ingat (fungsi kognitif) pada lansia di Panti Sosial Tresna Werdha Mulia Dharma Kubu Raya. ProNers, 3(1). Retrived from: http://jurnal.untan.ac.id/index.php/jmkepe rawatanFK/article/view/15029

Martono, H. H. \& Darmojo, R. B. (2011). Olah raga dan kebugaran pada usia lanjut. Buku Ajar Geriatrik (Ilmu Kesehatan Usia Lanjut). Jakarta: Balai Penerbit Fakultas Kedokteran Universitas Indonesia, 93-101.

Pangastuti, N. I. (2011). Latihan renang untuk lansia. JORPRES (Jurnal Olahraga Prestasi), 7(7), 32-37. Retrieved from https://journal.uny.ac.id/index.php/jorpres /article/view/10284

Parwati, N. M. (2013). Senam tera Indonesia meningkatkan kebugaran jantung paru lansia di Panti Werdha Wana Seraya Denpasar. Public Health and Preventive Medicine Archive, 1(1), pp. 1-6.
Pradipta, G., \& Sukoco, P. (2013). Model senam si buyung untuk pembelajaran motorik kasar pada siswa taman kanak-kanak. Jurnal Keolahragaan, 1(2), 130 - 141. doi:http://dx.doi.org/10.21831/jk.v1i2.256 9

Rohana, S. (2011). Senam vitalisasi otak lebih meningkatkan fungsi kognitif kelompok lansia daripada senam lansia di Balai Perlindungan Sosial Propinsi Banten. Jurnal Fisioterapi, 11(1).

Satoh, M., Ogawa, J., Tokita, T., Nakaguchi, N., Nakao, K., Kida, H., \& Tomimoto, H. (2014). The effects of physical exercise with music on cognitive function of elderly people: Mihama-Kiho project. PLoS ONE, 9(4), e95230. https://doi.org/10.1371/journal.pone.0095 230

Sudijono, A. (2012). Pengantar evaluasi pendidikan. Jakarta: PT RajaGrafindo.

Suharjana, S. (2008). Profil kebugaran fisik pelajar SLTA di Kabupaten Kulon Progo Daerah Istimewa Yogyakarta. Jurnal Cakrawala Pendidikan, 3(3). doi:http://dx.doi.org/10.21831/cp.v3i3.32 5

Turana, Y. (2013). Stimulasi otak pada kelompok lansia di komunitas. PD RI, Buletin Lansia, 19-24. 